\title{
A valós értékelés szerepe és mérése a hazai hitelintézeti szektorban*
}

\author{
Szücs Tamás - Ulbert József
}

A válság bebizonyította, hogy a valós értékelésre vonatkozó számviteli standardok szerepe különösen jelentős lehet a hitelintézeti szektorban. A tanulmány azt vizsgálja, hogy a valós értékelés, illetve az értékelésre vonatkozó nemzetközi és a gazdaságpolitikai színtéren bekövetkező hazai szabályozási változások milyen hatást gyakoroltak a hazai hitelintézetek mérlegeire. Külön hangsúlyt kap annak vizsgálata, hogy vajon a Magyarországon müködő külföldi tulajdonú hitelintézeti leányvállalatok és anyabankjaik eltérő módon reagáltak-e a válság kihivásaira. A szerzők kidolgoztak egy metódust a valós érintettség mérésére, és ennek segítségével azt vizsgálják meg, hogyan változott a hazai hitelintézeti szektor valósérték-érintettsége válság elött, a válság időszaka alatt és azt követően. Általánositva a problémát megállapitják, hogy a valósérték-érintettség mértéke pótlólagos kockázati faktor lehet a hitelintézetek müködési hatékonyságának megitélésekor, és a hazai leányvállalatok kissé más utat jártak, mint anyabankjaik.

Journal of Economic Literature (JEL) kódok: G01, M40, M41

Kulcsszavak: válság, valós érték számvitel, valós értékhierarchia

\section{A valós érték szükségessége}

A számviteli szabályozás történetét vizsgálva a valós értéken történő értékelés gondolatával először a 80-as évek elején találkozhatunk. A globalizáció elterjedésével párhuzamosan a világ pénzügyi piacai kiteljesedtek és soha nem látott mértékú fejlődésnek indultak. Új piacok jelentek meg a térképen, amelyek új befektetési lehetőségeket is magukkal hoztak, színesítve a hagyományos tranzakciók palettáját.

A klasszikus tranzakciók mellett egyre nagyobb szerephez jutottak az innovatív, újszerú pénzügyi termékek, az egyre bonyolultabb pénzügyi instrumentumok. Megértésük, beárazásuk, értékük meghatározása, modellezése egyre nagyobb kihívást jelent a befektetők számára.

\footnotetext{
* Jelen cikk a szerző nézeteit tartalmazza, és nem feltétlenül tükrözi a Magyar Nemzeti Bank hivatalos álláspontját.

Szücs Tamás a Pécsi Tudományegyetem Közgazdaságtudományi Kara Pénzügy és Számvitel Intézetének egyetemi adjunktusa.E-mail: tomi@ktk.pte.hu.

Ulbert József a Pécsi Tudományegyetem Közgazdaságtudományi Kara Pénzügy és Számvitel Intézetének habilitált egyetemi docense. E-mail: ulbert@ktk.pte.hu.
}

A magyar nyelvű kézirat első változata 2016. december 21-én érkezett szerkesztőségünkbe.

DOI: http://doi.org/10.25201/HSZ.16.3.5173 
Az újszerú pénzügyi instrumentumok elterjedésének felgyorsulását a pénzpiacokon az egyes kockázati szegmensekben érzékelhetően bekövetkező kockázatnövekedés táplálta, hiszen az innovatív termékek - legalábbis ötletgazdáik szerint - gyakran éppen a megnövekvő kockázattal szembeni védekezés eszközei voltak.

Nem tagadható az sem, hogy a tőke- és pénzpiacok fejlődésének egyik motorja a piaci forgalom bővítésére vonatkozó célkitǔzés lehetett, hiszen ez az innovatív termékek megalkotói és forgalmazói számára magában hordozta annak a lehetőségét, hogy különböző díjakon és szolgáltatásokon keresztül megcsapolják az ide érkező jövedelmeket.

E folyamatok eszkalálódása két-három évtizeden át zajlott, ami természetszerüleg az árak és az árfolyamok emelkedésével, illetve azzal járt együtt, hogy a tőkepiaci teljesítménymérés egyre jobban elszakadt a reálgazdasági teljesítményektől. Egyre inkább megkérdőjeleződött a piac értékmérő funkciója, különösen az olyan újszerű termékek esetében, amelyek mögött egyáltalán nem állt reálgazdasági teljesítmény.

Ezzel a fejlődési ütemmel sem a jogi szabályozás, sem a pénzügyi módszertan, sem pedig a számviteli szakma nem tudott igazából lépést tartani, s ezért amilyen ütemben az újszerú termékek „,beszivárogtak” a befektetők mérlegeibe és eredménykimutatásaiba (első körben és legintenzívebben a hitelintézeteknél, azon belül is a befektetési bankoknál volt ez a folyamat megfigyelhető), olyan ütemben jelentkezett a befektetők oldaláról egyre erősebben az igény arra, hogy azok valós értékét meghatározzák, illetve ezeket az értékbecsléseket kimutassák a mérlegek eszköz oldalán.

Beneish (1999) tanulmányában már az ezredforduló előtt megkongatta a vészharangokat. Véleménye szerint a valós értékelés jó eszköze lehet a pénzügyi beszámolók manipulálásának, mivel az egyes vagyonrészek felértékeléséból származó jövedelmek indokolatlan részvényárfolyam-emelkedéseket vonhatnak maguk után.

E tekintetben kissé megkésve ugyan, de a 80-as évek második felétől kezdve a vállalatértékelési és a számviteli szakma egy irányba kezdett mozogni. A vállalatok értékének meghatározásakor az eszköz alapú értékelések mellett megjelentek a jövőbeli hozamok értékteremtő funkcióját mérni igyekvő hozamérték-elvű módszerek. Ezzel párhuzamosan a nemzetközi számviteli gyakorlatban a költségalapú értékelést kezdte felváltani a piaci alapú, valós értékelés (Shaffer 2012).

A párhuzamosság ellenére a pénzügyi megközelítés a hozamérték-elv bevezetésével más választ adott a kihívásra, mint a számviteli szakma, amely továbbra is az eszközök beárazásában látja a megoldás kulcsát. A pénzügy esetében ugyanis az eszközökről átterelődött a hangsúly az eszközök hozamtermelő képességének mérésére (Bélyácz 2013). 


\section{A valós érték fogalma}

Az 1606/2002/EK európai parlamenti és tanácsi rendelet szerint 2005. január 1-jétől (hazánkban 2007-től) minden tőzsdén jegyzett társaság konszolidált beszámolóját a nemzetközi számviteli standardokkal összhangban kell elkészíteni, melynek során kötelező a valós értékelés alkalmazása.

Valós érték alatt ezen irányelv azt az összeget érti, amelyért jól tájékozott, ügyleti szándékkal rendelkező felek között, szokásos piaci feltételek szerint lebonyolított ügylet keretében egy eszközt el lehet cserélni, vagy egy kötelezettséget rendezni lehet.

E definíció általános megfogalmazása és a gyakorlatban felmerülő alkalmazhatósági problémái miatt kezdettől fogva komoly kritikát kapott a szakirodalomban és a gyakorlatban egyaránt.

Barth (2004) szerint a vállalati vagyon valós értékének becslése időben változó, hiszen piaci szempontok jelennek meg benne, azaz elveszti időbeli stabilitását, a változékonyság pedig pótlólagos kockázati tényezőnek tekinthető, hiszen felfelé ívelő, növekedési szakaszban a menedzsment számára önigazolásként szolgálhat, ugyanakkor visszaesések időszakában eszkalálhatja a folyamatokat. A tényleges piaci háttérrel nem, vagy csak korlátozottan bíró eszközök esetében az értékelés bizonytalan, a gyakorlattól gyakran távol eső feltételeket alkalmazó modelleken nyugszik, így az érték becslése sem lehet mentes a hibáktól, ezért a valós értékelést csak egy állandóan likvid piaci környezetben lehet alkalmazni, ahol a szereplők információszerzésének nincsenek akadályai.

Hitz (2007) szerint a valós értékelés alkalmazási feltételei idealizáltak, így a segítségükkel előállított piaci alapú értékelések is csak hipotetikusak, hiszen a definíció nem határozza meg például, hogy vételi vagy eladási oldali tranzakcióról van-e szó. Nem ad felvilágosítást arról sem, hogy melyik időpontot kell mérvadónak tekinteni a mérlegérték meghatározásakor, vagy mit kell pontosan érteni a „szokásos” piaci feltételek kitétel alatt.

Ezeket a negatívumokat csak részben ellensúlyozta, hogy a definíció viszont lehetőséget adott arra is, hogy olyan eszközöket jelenítsenek meg a mérlegben, amelyek korábban mérlegen kívüli tételek voltak, és mint ilyenek a befektetők számára láthatatlanok maradtak (Bosch 2012).

Bromwich (2007) is jó összefoglalót ad a valós érték definíciója mögött húzódó, sokszor nem túl gyakorlatközeli feltételezésekről. 


\section{1. táblázat}

A valós érték gyakorlattól távol eső feltételrendszere

\begin{tabular}{|c|c|}
\hline Csoport & Mögöttes megfontolás \\
\hline \multirow[t]{3}{*}{ 1. Árak } & $\begin{array}{l}\text { a) A valós érték mérésekor felhasznált árak piacon alapulnak, függetlenül } \\
\text { a gazdálkodó egység kereskedési céljától. }\end{array}$ \\
\hline & b) Az ár eladási (kilépési) ár. \\
\hline & c) Az árak nem tartalmazzák a tranzakciós költségeket. \\
\hline \multirow[t]{2}{*}{ 2. Piac } & a) A tranzakciók a szokásos (elsődleges) piacon (legnagyobb volumen és aktivitás) zajlanak. \\
\hline & $\begin{array}{l}\text { b) Ha több piac is létezik, akkor a legelőnyösebb az lesz, ahol a profitmaximalizálás } \\
\text { kivitelezhető. }\end{array}$ \\
\hline \multirow{5}{*}{$\begin{array}{l}\text { 3. Piaci } \\
\text { szereplők }\end{array}$} & a) Nem kapcsolt, tehát független felek. \\
\hline & $\begin{array}{l}\text { b) Jól informált szereplők képesek megérteni a vagyonelem és a tranzakció alapvető } \\
\text { tulajdonságait. }\end{array}$ \\
\hline & $\begin{array}{l}\text { c) A szükséges információk megszerzésénél az elvárható óvatossággal járnak el, és } \\
\text { mindent megtesznek az információk megértése érdekében. }\end{array}$ \\
\hline & d) Az egyes tranzakciók nem kényszer hatása alattiak. \\
\hline & e) Az egyének rendelkeznek az ügyletkötéshez szükséges képességgel és szándékkal. \\
\hline \multirow{7}{*}{$\begin{array}{l}\text { 4. A feltételezett } \\
\text { használat }\end{array}$} & a) A pénzügyi eszközöket azok cash-flow-struktúrája egyértelműen definiálja. \\
\hline & $\begin{array}{l}\text { b) Az eszközöknél annak az ajánlati árnak a becslése, amely a legjövedelmezőbb } \\
\text { felhasználást jelenti a piaci szereplők általi értékelés időpontjában, ami: }{ }^{1}\end{array}$ \\
\hline & $\begin{array}{l}\text { - használati alapú értékelés (más eszközökkel együttesen használható): legmagasabb } \\
\text { használati érték meghatározása; }\end{array}$ \\
\hline & $\begin{array}{l}\text { - csere (önállóan használható) esetében egyedi értékelés alapján meghatározott } \\
\text { hasznosítási érték. }{ }^{2}\end{array}$ \\
\hline & c) A b) pontban említett árak közül a legmagasabb lesz a valós érték. \\
\hline & $\begin{array}{l}\text { d) A használat fizikailag lehetséges, jogilag elfogadható és pénzügyileg } \\
\text { megvalósítható. }\end{array}$ \\
\hline & $\begin{array}{l}\text { e) Kötelezettségek átruházása azonos hitelezési kockázat (nem teljesítési kockázat) } \\
\text { mellett lehetséges. }\end{array}$ \\
\hline \multirow{3}{*}{$\begin{array}{l}\text { 5. Számviteli } \\
\text { feltételezések }\end{array}$} & Hagyományos számviteli feltételezés: \\
\hline & $\begin{array}{l}\text { - A mérést valamennyi elkülöníthető vagyonelem, illetve ezek aggregált csoportjai } \\
\text { esetében kell végrehajtani. }\end{array}$ \\
\hline & - A mérés figyelembe veszi az eszköz állapotát és elhelyezkedését, ha ez releváns. \\
\hline
\end{tabular}

Ameddig az általános piaci és gazdasági környezet megbízható, stabil volt, addig a definíció minden hibája ellenére tulajdonképpen működőképes maradt. A problémák azzal párhuzamosan kezdtek el sűrűsödni, ahogy az újabb válság kezdett kiteljesedni.

\footnotetext{
${ }^{1}$ A használatértékelési premissza (in-use valuation premis) feltételezése, hogy a piaci résztvevők az eszközt más eszközökkel együtt használni kívánják, tehát az eszköz valós értékét az eszközök közötti szinergiák befolyásolják, jellemzően növelik.

${ }^{2} \mathrm{~A}$ csereértékelési premissza (in-exchange valuation premis) esetében feltételezhető, hogy az eszköz önmagában hasznosítható, és a piaci szereplők számára így érhető el vele a maximális haszon.
} 


\section{Valós érték és a válság}

Vajon a valós értékelés lehetősége Pandóra szelencéjét nyitotta-e ki, azaz hozzájárult-e a válság kialakulásához, későbbi eszkalálódásához, vagy éppen ellenkezőleg, megnyitotta-e a lehetőségét annak, hogy segítségével a válságot kezeljük?

Több szerző is úgy gondolja (Wallison 2008; Whalen 2008), hogy a valós értékelés prociklikus természete lehetett a legfőbb oka a válságnak. Kiemelik, hogy a valós értékelés az elsődleges oka a vagyoni érték elöre nem látható csökkenésének és a pénzügyi vállalkozások közötti szintén elöre nem jelzett instabilitás növekedésének. A FASB ASC $820^{3}$ alkalmazása, illetve a valós értéken alapuló banki kapitalizáció számítása okozta a lefelé irányuló spirált a vagyonértékben, illetve hozzájárult a szolvencia nagymértékű csökkenéséhez. A futamidő végéig megtartott instrumentumok kereskedelmi eszközök közé sorolása olyan megoldás, amely üzleti érdeket szolgált. Kritikájuk szerint, gyakorta olyan eszközök is átsorolásra kerültek, melyeknek nincs objektív piaci ára.

Más vélekedések szerint (Pozen 2009; Le Pan 2008) a valós érték alapú elszámolás nem lehet okozója a válságnak. Sőt, egyes vélemények ezen is túlmenve azt hangsúlyozzák, hogy a bankok és a biztosítók menedzsereinek sokkal könnyebb hibáztatni a számviteli standardokat, mint a hitelintézeti felügyelet alatt álló tőkemegfelelési szabályokat. A valósérték-elszámolások elöbb jelezték azokat a hatásokat, problémákat, amelyek a másodlagos jelzálogpiaci hitelek és a nem-teljesítéskori csereügyletek rossz döntéseinek következtében álltak elő (Rerolle 2008).

Power (2008) szerint a standard alkotóinak sokkal több időt kellett volna eltölteni az értékelés átdolgozásával ahhoz, hogy sokkal szélesebb körben lehessen használni a valós értékelési modellt. Egyszerüen túl korán került bevezetésre.

Veron (2008) és Shamkuts (2010) munkáikban a likviditáshiányt és a prociklikusságot jelölik meg a valós értékelés két fontos problémájaként. A valós érték meghatározásához elengedhetetlenül szükséges a piaci ár. Ha ez nem áll rendelkezésre, akkor a cégek különböző modellek irányába fordulnak, amelyek segítségével próbálják előre jelezni a jövőbeli folyamatokat. Ez jól tervezhető, kiszámítható gazdasági környezetben viszonylagos megbízhatóság mellett elfogadható törekvés, azonban a válság időszakában már nem. Amellett foglalnak állást, hogy az előírások módosítása égetően szükséges, hiszen a jelenlegi szabályozás nem számol az esetleges negatív hatásokból származó adatvesztéssel és ennek hatásaival a pénzügyi beszámolókban. Kiküszöbölendő hiányosságként fogalmazták meg, hogy a jelenlegi mérési rendszert a piaci feltételekkel összhangban korrigálni kell, és megfelelő kiegészítő információkkal kell ellátni a beszámolókban.

\footnotetext{
${ }^{3}$ US GAAP keretében meghatározott valós értékelési standard, korábban FAS 157.
} 
Laux és Leuz (2009a; 2009b) úgy véli, hogy a valós értékelés nem tehető felelőssé a válság gerjesztésében, de nem is tekinthető másnak, mint egy lehetséges mérési modellnek. Véleményük szerint a jelenlegi szabályok önmagukban nem jelentik a krízis forrását, ám azok kölcsönhatása más intézményi keretekkel problémát okozhat. Hangsúlyozzák továbbá, hogy a bekerülési értékhez (History Cost Accounting, HCA) visszatérés nem tekinthető megoldásnak, hiszen az még kevésbé tükrözi az eszköz jelenlegi értékét. A megoldás csak rövid távú lehet: kisebb mértékű értékvesztés elszámolása. A valós értékelés bírálóinak azonban nem szabad figyelmen kívül hagyniuk azt a tényt, hogy a modell korai figyelmeztető jelzéseket küldött a közelgő válságra, kényszerítve a bankokat a megfelelő intézkedés megtételére. Azaz a valós értékelés minden hibája ellenére ténylegesen csökkentette a válság súlyosságát.

Allan és Carletti (2008) a valós értékelés módszertanának legfőbb problémáját abban látja, hogy nem kellően likvid piaci környezetben a valós értéket rendkívül nehéz megbecsülni, legtöbb esetben megbízhatatlan eredményt kapunk. A valós érték ebben a felfogásban tulajdonképpen a piac likviditási szintjének egyfajta méröszámaként határozható meg. Gorton (2008) szerint a másik lényegi probléma az, hogy a valós értékelés mechanizmusa nyomást gyakorolt a hitelintézetekre, és a bizonytalan jövőbeli előrejelzésekre épített becslési folyamat eredményeképpen gyakran olyan mértékú értékvesztés elszámolására került sor, ami az egyes vagyonrészek alulértékeléséhez vezetett.

Laux és Leuz (2010) megcáfolja azt az amerikai álláspontot, miszerint néhány nagybank esetét kivéve a valós értékelésnek korlátozott szerepe volt a bankok eredménykimutatása és a szavatoló tőkéje alakulásában, mivel e bankok önállóan döntöttek subprime kitettségük növeléséről, és problémáikat nem a valós értékelés módszertanának köszönhetik. Természetesen a téma nem csak a szúkebben vett szakmai berkekben fókuszálódott. A Bank of Canada egykori vezetője, David Dodge és a Forbes Media elnöke, Steve Forbes vehemensen bizonygatta, hogy a valós értékelés felgyorsította és felerősítette a válságot (McFarland - Partridge 2008). Nicholas Sarkozy (2008) egy 2008-as beszédében szintén kihangsúlyozta, hogy „a bankok alá vannak vetve a számviteli szabályoknak, amelyek nem nyújtanak kellő garanciát a kockázatok elkerülésére, sőt, válság esetén inkább súlyosbítják a helyzetet ahelyett, hogy tompítanák a sokk erejét."

Az U.S. Federal Deposit Insurance Co. volt elnöke, William Isaac szerint a valós értékelés alkalmazása szükségtelenül nagy mértékben érintette a bankok tőkéjét, ami hozzájárult a válság kiteljesedéséhez és a gazdasági visszaeséshez (Magnan 2009). 


\section{Valós értékelés a válság után}

A válság legfontosabb tanulsága a valós értékelés szempontjából az, hogy szükség van átgondolt szabályozásra a pénzügyi stabilitás fenntartása érdekében. Az indokoltsága abból fakad, hogy a hitelintézetek profitorientált magatartása káros hatásokat vonhat maga után (Pitz - Schepp 2013).

A gyakorlati tapasztalatok és a fenti kritikák hatására az IFRS 13. standard 2011 májusában került kibocsátásra és 2015. január 1-jétől hatályos. Egységes elvi keretrendszert ír elő a valós érték meghatározására, amely a pénzügyi és a nem pénzügyi eszközökre egyaránt alkalmazható. Az IFRS 13. a valós értéket a következő módon definiálja: „Az az ár, amelyet egy eszköz értékesítésekor kapnának, illetve egy kötelezettség átruházásakor kifizetnének egy piaci szereplők között létrejött szabályos jogügylet alapján az értékelés időpontjában."

A valós érték meghatározása során néhány kulcsfeltételt rögzíteni kell annak érdekében, hogy az értékelés eredménye megbízható legyen. A gazdálkodó egységnek meg kell határoznia

- a valós értékelés elszámolási egységeit (vagyis az értékelt eszközt vagy kötelezettséget),

- az elsődleges piacot, amelyen a szokványos tranzakció végbemenne, és azokat a feltevéseket, amelyeket a piaci szereplők alkalmaznának,

- hogy nem pénzügyi eszközök esetében mi lehetne az eszközök legmagasabb fokú és legjobb hasznosítása annak figyelembe vételével, hogy az eszközök más eszközökkel történő kombinációban vagy önállóan használhatók-e.

Az új standard hangsúlyozza, hogy a valós érték piaci alapú értékelés. Egyes eszközök és kötelezettségek esetében rendelkezésre állhatnak megfigyelhető és öszszehasonlítható piaci ügyletek vagy piaci információk. Kovács (2012) szerint az új standard a piaci értékelés elsődlegessége mellett a szektorsemlegességre hívja fel a figyelmet. Más eszközök és kötelezettségek esetében előfordulhat, hogy ilyenekkel az értékelő nem rendelkezik. Ettől függetlenül a valós értéken történő értékelés célja mindkét esetben ugyanaz: megbecsülni azt az árat, amelyen az eszköz értékesítésére vagy a kötelezettség átruházására irányuló szabályos ügylet végbemenne a piaci szereplők között az értékelés időpontjában a fennálló piaci feltételek mellett.

Erre az értékre gyakran mint „likvidációs értékre” hivatkoznak. Ebben az értelemben valós érték alatt egy kilépési árat kell érteni, ami az értékelés időpontjában

\footnotetext{
${ }^{4}$ Nemzetközi Pénzügyi Beszámoló Rendszer 13. Valós értékelés c. standard.
} 
a releváns piaci szereplők (az eszköz tulajdonosa vagy a kötelezettség kötelezettje) között jön létre.

A gazdálkodó egység olyan értékelési technikákat köteles használni, amelyek az adott körülmények között megfelelőek, és amelyek tekintetében elegendő adat áll rendelkezésre a valós érték meghatározásához, a vonatkozó megfigyelhető input-adatok használatának maximalizálásával és a nem ismert információk használatának minimalizálásával. Az IFRS 13 (néhány kivétellel) megköveteli a gazdálkodótól, hogy egy olyan hármas tagozódású „valós érték hierarchiába” csoportosítsa ezeket az értékeléseket és közzétételeket, amely az inputok természetén alapszik.

1. szint - Azon pénzügyi eszközökre és kötelezettségekre vonatkozik, amelyek beazonosítható, aktív piacon cserélnek gazdát. A feltételek megvalósulásához a következő két feltétel egyidejű teljesülése szükséges: a) egy létező piac, ahol az eszközökre és a kötelezettségekre vonatkozóan kereslet és kínálat jelentkezik; b) a tranzakció végrehajtható lenne a gazdálkodó által megadott áron, adott értékelési időpontban.

2. szint - Olyan eszközök sorolódnak ide, amelyek nem az 1. szint által alkalmazott, az eszközre vagy kötelezettségre vonatkozó, megfigyelhető jegyzett árak (a piaci árból közvetlenül vagy közvetve levezetve). Ezeket az instrumentumokat a nem teljes mértékben független árképzés miatt nem lehet az 1 . szintbe sorolni. A következő esetek tipikusak e szint besorolásakor: a) ismert a jegyzett ár az adott instrumentumhoz hasonló eszközökre és kötelezettségekre; b) ismert a jegyzett ár az adott instrumentummal azonos vagy hasonló eszközökre és kötelezettségekre, azonban a piac az értékelés pillanatában nem múködik; c) más indikátorok is beazonosíthatóak a jegyzett ár mellett az adott instrumentumra vonatkozólag: kamatráta, hozamgörbe az adott jegyzési időszakra vonatkozólag, volatilitás, előtörlesztés gyorsasága, veszteséggel kapcsolatos megszorítások, hitelkockázat, fizetésképtelenségi ráta stb.; d) az instrumentum árának levezetése piaci folyamatokból statisztikai módszerek segítségével lehetséges (pl.: korreláció, regresszió, átlagok).

3. szint - Ha az adott instrumentum esetében nem állnak rendelkezésre releváns megfigyelhető inputok, akkor a valós érték meghatározására nem megfigyelhető paramétereket kell használni, ezáltal figyelembe vehetők olyan helyzetek, amelyekben az értékelés időpontjában kicsi a piaci aktivitás. A valós értéken történő értékelés célja továbbra is ugyanaz marad: reális kilépési ár meghatározása az értékelés időpontjában azon piaci szereplő szemszögéből, aki az eszköz tulajdonosa vagy a kötelezettség kötelezettje. A nem megfigyelhető paramétereknek ezért tükrözniük kell azokat a feltételezéseket, amelyeket a piaci szereplők használnának az eszköz vagy a kötelezettség árazásakor, ideértve különösen a kockázattal kapcsolatos feltételezéseket is. A gazdálkodó egység köteles az adott körülmények között elérhető legjobb információkat felhasználni, amelyek részben magukban foglalhatják a gazdálkodó egység saját adatait is. 
Az első két szint értékelési logikája alapvetően a piaci információkra épít (Mark to Market). A kapott eredmények megbízhatóságát a piaci folyamatok igazolják vissza. A 3. szint értékelési technikái azonban elsősorban modellszámításokon alapulnak (Mark to Model), amelyre az IFRS 13 több értékelési módszert ajánl a gazdálkodók számára: piaci, költség- (bekerülési érték) vagy hozamalapú megközelítést ${ }^{5}$ (Takács 2014 és 2015).

A standard megjelenését követően (a válság súlyosabb időszakának a végén) a valós értékeléssel foglalkozó szakirodalom és gyakorlat a válság előttinél jóval cizelláltabb, sokszínúbb és politikai hatásoktól mentes kritikákat fogalmazott meg, amelyek fókuszában már nem a felelős keresése, hanem sokkal inkább szakmai kérdések álltak.

A válság utáni szakirodalom is megosztott a valós értékelés megítélését tekintve, de már megjelennek új elemek a korábbi kritikus megjegyzések kiegészítéseként. Ezen új vonulatok közül tanulmányunk lényegi mondanivalóját illetően talán a legfontosabb, hogy a valós értékelést pótlólagos kockázatként, illetve lehetőségként egyaránt fel lehet fogni. Reidl és Serafeim (2011) vizsgálatai szerint például a pénzügyi instrumentumok valós értéken történő elszámolása növeli a töke költségét, azaz magasabb kockázati szintet von maga után. Shaffer (2012) kiemeli, hogy a valós értékelés nem minden esetben objektív, érthető vagy transzparens. Különösen az inaktív, likvid piacok hiányában vagy a piaci krízisek időszaka alatt vezethet téves következtetésekhez. Más szerzők (Barth et al. 2012) szerint ugyanakkor a valós értékelés közvetlenül nem okozója a válságnak, mivel az általa elvégzett értékelés nem realizált nyereséget jelent, így az osztalék finanszírozási alapjaként sem vehető figyelembe. Azt is megemlítik, hogy a valós értéken alapuló gondolkodás (ellentétben a bekerülési értékkel) képes a jó és a rossz hír fogalmát egyaránt korrekten kezelni. Brit és német cégeket vizsgálva Christensen és Nikolaev (2013) azt állapította meg, hogy a nem pénzügyi eszközök értékelési módszertanának megválasztásában sokkal fontosabbak a gazdasági és pénzügyi szabályozók, mint maguk a piaci folyamatok.

A válság utáni finomítottabb megközelítések jó összefoglalóját adják Greenberg és munkatársai (2013). Tanulmányukban a valós értékeléssel szemben alapvetően három kritikát fogalmaznak meg:

a) az objektív „piaci ár” fogalma nagyon zavaró, kimondottan félrevezető lehet kevésbé likvid piacokon;

b) a valós értékelés mechanizmusa nagyobb mértékben hozzájárulhat az adott bank pénzügyi befektetéseinek megfertőzéséhez, ha azok szoros korrelációt mutatnak bizonyos befektetési portfóliókkal vagy a hálózati partnerek pénzügyi kapcsolataival;

\footnotetext{
${ }^{5}$ Hozamalapú értékelés alatt diszkontált eredményt vagy diszkontált cash-flow-t kell érteni.
} 
c) a valós értékelésnek krízishelyzetben sokszor kényszerítő hatása lehet az egyes eszközök értékesítésére, holott hosszabb távú tartásával magasabb ár lenne realizálható.

Összességében megállapíthatjuk, hogy a vonatkozó szakirodalom és gyakorlat meglehetősen sokszínűen viszonyul a valós értékelés módszertanához. A válság utáni szakirodalomban nincs olyan vélemény, amely egyértelműen elítélő lenne. Még a válság kiváltó okaként aposztrofált hozzáállásokban sem. Olyan véleményt sem találtunk, amely viszont csak és kizárólag azt hangsúlyozta volna, hogy a valós értékelés segítségével a válságok kezelhetők lennének. Ez arra vezethető vissza, hogy a legtöbb szerző belátja a valós értékelés előnyeit a bekerülési értékhez képest. Ugyanakkor az is világosan látszik, hogy melyek azok a hátrányok, amelyeket a válsághelyzet felerősíteni látszott.

E dolgozat szerzői hajlanak az arany középút felé, miszerint a valós értékelésnek szerepe lehetett a válság előidézésében, de ez önmagában biztosan nem nevezhető meg egyedüli okként. A másik oldalnak is megvan a maga igazsága, mert avatott és jó kezekben a valós értékelés valóban képes lehet arra, hogy problémákat kezeljen. Hazai hitelintézetekre vonatkozó empirikus kutatásunkban is végigfut ez a kettősség. Nem vitatható azonban, hogy a valós érték minden hibája és hiányossága ellenére egyre szélesebb körben alkalmazott eszközértékelési módszerré vált/válik. Szerepe különösen felértékelődött a hitelintézeti szektorban, hiszen a válság középpontjában is ez a szektor állt.

\section{A hazai hitelintézeti szektor valósérték-érintettségének mérése}

A valós értékelésre vonatkozó nemzetközi empirikus vizsgálatok általában az egyes szintek értékeinek relevanciáját vizsgálják (Bagna et al. 2014; Kolev 2008 Goh et al. 2009; Song et al. 2010). Jövőbeni kutatásaink során tervezzük a részletesebb értékrelevancia-vizsgálatokat is a hazai hitelintézeti szektorban, de jelen tanulmányunkban egyelőre a téma megalapozásaként fontosabbnak tartottuk annak bemutatását, hogy egyáltalán milyen súlyú a hazai hitelintézeti szektorban a valós értékelés szerepe a mérlegek eszköz és forrás oldalain.

Kidolgoztuk a valósérték-érintettség egy lehetséges mérési technikáját, és az alábbi kérdésekre kerestük a választ.

a) Hogyan változik a hazai hitelintézetek mérlegeiben a valós érintettség mértéke?

b) Megfigyelhetők-e a válság előtt, közben és után jellegzetes mintázatok a valósérték-érintettség időbeli alakulásában, azaz az érintettség mértéke utalhat-e közelgő válságra, vagy inkább a válságot létrehozó okként kell a mintázatokra tekintenünk? 
c) Vannak-e szignifikáns eltérések az érintettség mintázataiban a leányvállalatok és az anyavállalatok között?

d) Milyen specialitások figyelhetők meg az érintettségi mintázatokban az OTP mint hazai vezető bank vonatkozásában?

\subsection{Az empirikus vizsgálat adatbázisa, transzformációi és időhorizontja}

Az adatbázist az OTP, valamint további öt, a hazai hitelintézeti szektor meghatározó szereplőinek és anyabankjaiknak tíz évre vonatkozó (2006-2015) éves konszolidált beszámolóiból állítottuk össze ${ }^{6}$, így IFRS szerinti azonos struktúrájú mérlegeket és eredménykimutatásokat ${ }^{7}$ tartalmaz. A tízéves adatsort négy időszakra bontottuk (2. táblázat), mert így mutatható be a válság és a valós értékelés hatásmechanizmusának időszaki változása.

\section{2. táblázat}

\section{Az empirikus vizsgálat periódusai}

\begin{tabular}{l|l} 
Válság előtti időszak & 2006-2008, 3 év \\
\hline Válság időszaka & 2009-2010, 2 év \\
\hline Válság után első periódus & 2011-2012, 2 év \\
\hline Válság után második periódus & 2013-2015, 3 év \\
\hline
\end{tabular}

A fenti periódusokra vonatkozóan az éves nominális adatokból időszaki átlagos éves adatokat számoltunk egyszerű számtani átlagolással, majd ezt követően az eszköz és forrás oldali összegző sorok megfelelő értékeit a mindenkori átlagos mérlegfőöszszegek százalékában fejeztük ki. A leánybankok és az anyabankok adatait átlagoltuk, ezért ahol leánybank szerepel az adatközlésben, az a leánybankok átlagaként értelmezendő.

\subsection{A valósérték-érintettség fogalma és mérése}

Az éves beszámolók tanulmányozása során azt tapasztaltuk, hogy a valós értékelés eszközrendszere csak az alábbi mérlegsorokon volt kimutatható ${ }^{\text {. }}$

\footnotetext{
${ }^{6}$ Intesa Sanpaolo Group - CIB Bank Zrt., Raiffeisen Zentralbank Österreich AG - Raiffeisen Bank Zrt., Bayerische Landesbank (MKB államosítása után is folytatva az adatsort!) - MKB Bank Zrt., KBC Group - K\&H Bank Zrt., UniCredit Group - UniCredit Bank Hungary Zrt.

${ }^{7} \mathrm{Az}$ adatok a magyar hitelintézetek esetében a https://www.e-beszamolo.hu/ feltöltött beszámolói alapján (letöltés ideje: 2016. március 5.), míg az anyabankok esetében a honlapokon közzétett éves beszámolók (annual report) alapján kerültek legyújtésre. A szerzők az adatbázishoz hozzáférési lehetőséget biztosítanak, előzetes regisztráció után. Kérjük, az érdeklődők e-mail-ben keressenek!

${ }^{8}$ Eszköz oldalon nem lehetett egyértelmúen alábontani az adatokat, ezért együtt kezeltük az érintett sorokat.
} 


\section{3. táblázat}

\section{Az érintettség kiterjedése a mérlegekben}

\section{Érintett eszközök}

Eredménnyel szemben elszámolt pénzügyi eszközök

Származékos pénzügyi eszközök aránya

Értékesíthető pénzügyi befektetések aránya

\section{Érintett források}

Eredménnyel szemben elszámolt kötelezettségek

Az induló adatok leírt transzformációi után jutottunk el a valósérték-érintettség primer mutatószámához, ami azt mutatja meg, hogy eszköz és forrás oldalon a valós értékelés módszertana milyen mértékben volt jellemző az adott bankra, pontosabban a bankok átlagára.

A primer érintettség a mérlegfőösszeg százalékában kifejezett, és egyelőre nem tartalmazza a valós érték szintenkénti belső struktúráját.

Az input-adatok fenti metódus szerinti aggregálása után kapott primer érintettségi értékek időbeli alakulását mutatja az 1. és 2. ábra az eszközök és a források oldalán.

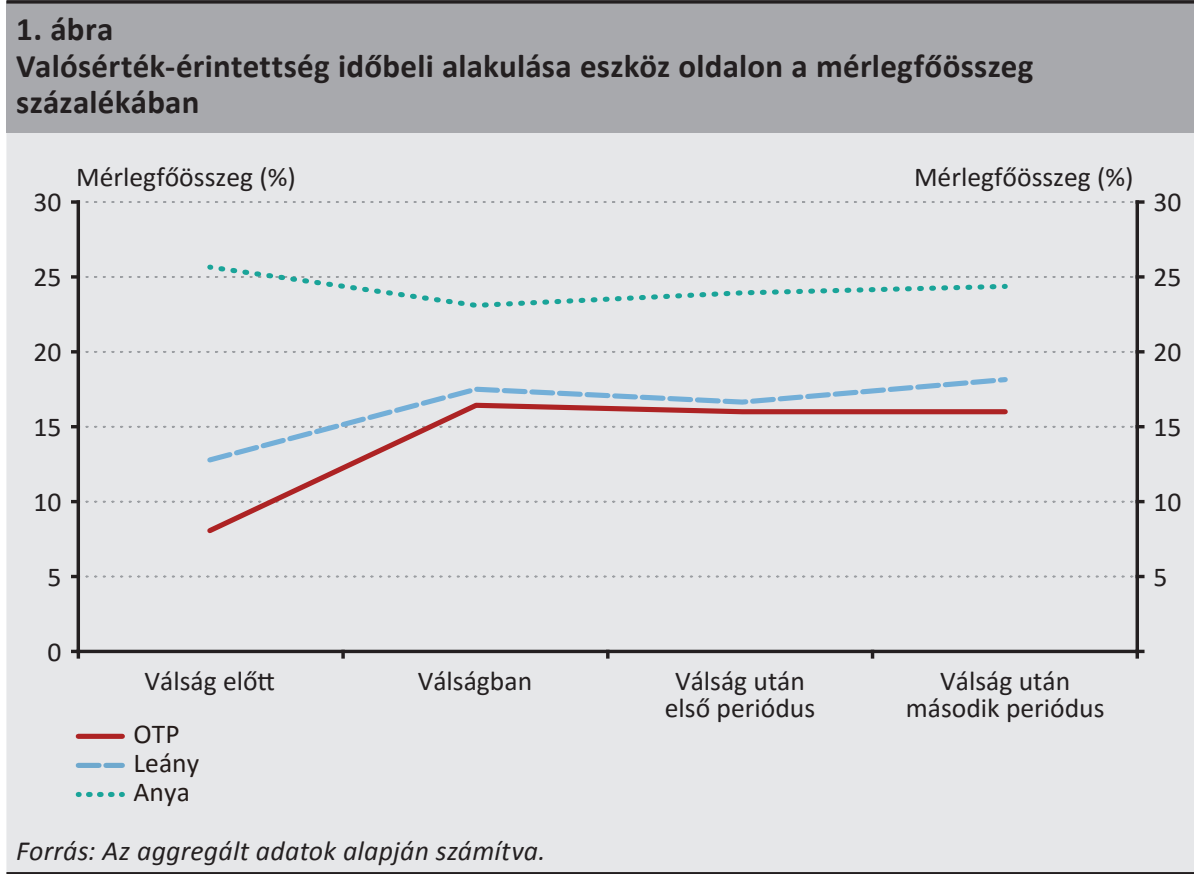




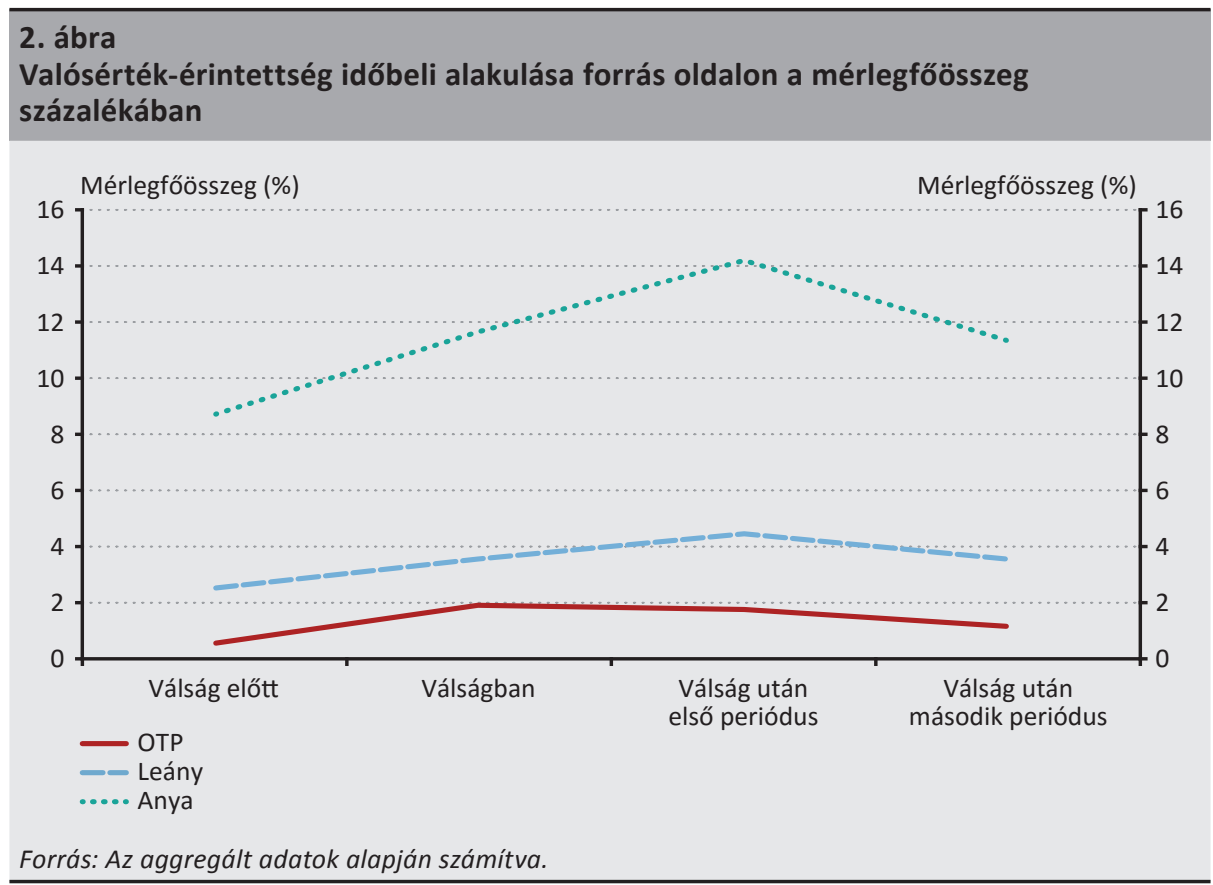

Ha figyelembe vesszük a valós értékelés szintstruktúráit is, akkor még tökéletesebb érintettségi adatokat kapunk (szekunder érintettség).

\section{4. táblázat}

A valós értékelés szintenkénti súlyai az érintett eszközökön belül

\begin{tabular}{l|c|c|c}
\multicolumn{1}{c|}{ 1. szint súlya az érintett eszközökön belül } & OTP & LEÁNY & ANYA \\
\hline Válság előtt & $63,79 \%$ & $47,75 \%$ & $51,06 \%$ \\
\hline Válságban & $87,14 \%$ & $49,43 \%$ & $47,49 \%$ \\
\hline Válság után első periódus & $58,83 \%$ & $48,83 \%$ & $44,17 \%$ \\
\hline Válság után második periódus & $78,39 \%$ & $72,13 \%$ & $54,10 \%$ \\
\hline \multicolumn{1}{|c|}{ 2. szint súlya az érintett eszközökön belül } & OTP & LEÁNY & ANYA \\
\hline Válság előtt & $20,12 \%$ & $50,34 \%$ & $42,65 \%$ \\
\hline Válságban & $9,66 \%$ & $49,41 \%$ & $48,54 \%$ \\
\hline Válság után első periódus & $40,86 \%$ & $49,48 \%$ & $51,50 \%$ \\
\hline Válság után második periódus & $21,17 \%$ & $27,19 \%$ & $43,00 \%$ \\
\hline \multicolumn{1}{|c|}{ 3. szint súlya az érintett eszközökön belül } & OTP & LEÁNY & ANYA \\
\hline Válság előtt & $16,09 \%$ & $1,91 \%$ & $7,20 \%$ \\
\hline Válságban & $3,20 \%$ & $1,16 \%$ & $3,97 \%$ \\
\hline Válság után első periódus & $0,31 \%$ & $1,69 \%$ & $4,33 \%$ \\
\hline Válság után második periódus & $0,44 \%$ & $0,68 \%$ & $2,90 \%$ \\
\hline
\end{tabular}

Forrás: Az aggregált adatok alapján számítva. 


\begin{tabular}{|c|c|c|c|}
\hline \multicolumn{4}{|c|}{$\begin{array}{l}\text { 5. táblázat } \\
\text { A valós értékelés szintenkénti súlyai az érintett forrásokon belül }\end{array}$} \\
\hline 1. szint súlya az érintett forrásokon belül & ОтР & LEÁNY & ANYA \\
\hline Válság előtt & $0,01 \%$ & $0,86 \%$ & $23,23 \%$ \\
\hline Válságban & $0,11 \%$ & $1,62 \%$ & $9,87 \%$ \\
\hline Válság után első periódus & $0,26 \%$ & $0,56 \%$ & $7,84 \%$ \\
\hline Válság után második periódus & $0,16 \%$ & $0,61 \%$ & $12,24 \%$ \\
\hline 2. szint súlya az érintett forrásokon belül & OTP & LEÁNY & ANYA \\
\hline Válság előtt & $99,99 \%$ & $96,99 \%$ & $68,70 \%$ \\
\hline Válságban & $99,89 \%$ & $98,16 \%$ & $85,87 \%$ \\
\hline Válság után első periódus & $95,47 \%$ & $96,45 \%$ & $87,77 \%$ \\
\hline Válság után második periódus & $99,84 \%$ & $99,25 \%$ & $85,59 \%$ \\
\hline 3. szint súlya az érintett forrásokon belül & OTP & LEÁNY & ANYA \\
\hline Válság előtt & $0,00 \%$ & $2,15 \%$ & $8,07 \%$ \\
\hline Válságban & $0,00 \%$ & $0,22 \%$ & $4,26 \%$ \\
\hline Válság után első periódus & $4,26 \%$ & $2,99 \%$ & $4,39 \%$ \\
\hline Válság után második periódus & $0,00 \%$ & $0,14 \%$ & $2,16 \%$ \\
\hline
\end{tabular}

\subsection{Az empirikus vizsgálat legfontosabb eredményei a primer érintettség vonatkozásában (1., 2. ábra)}

- Az eszköz oldalon az érintettség lényegesen nagyobb mértékű, mint a forrás oldalon. Ez a megállapítás független időszaktól és besorolástól is. Nyilván ez a mérleg sajátosságából is adódik, hiszen forrás oldalon a saját tőke eleve nem értékelhető valós értéken.

- A nemzetközi színtéren mozgó anyabankok érintettsége lényegesen meghaladja leánybankjaik és az OTP érintettségét is. Ez a megállapítás minden vizsgált időszakban megállja a helyét, eszköz és forrás oldalon egyaránt. A primer érintettség mértéke ezek szerint visszavezethető a méretre és a nemzetközi jellegre egyaránt.

- A legkevésbé érintett az OTP. Ez a megállapítás szintén minden időszakra kiterjeszthető, és igazoltnak tekinthető eszköz és forrás oldalon is. Az OTP-n nincs anyabanki „nyomás” a vagyonelemek értékelése tekintetében. A leánybankok vagyoni szerkezetének kialakításában, értékelésében az anyavállalati utasítások minden bizonnyal komoly szerepet játszanak.

- Az OTP eszköz oldali valósérték-stratégiája és annak válsághoz való viszonyulása szignifikánsan eltér az anyabankok eszköz oldali valósérték-válságstratégiájához képest. Az OTP eszközoldali primer érintettségi szintje válság előtt messze a legkisebb volt. A válság időszakában viszont kétszeresére nőtt, aztán gyakorlatilag 
stagnált. Az anyabankok primer érintettsége válság előtt volt a legnagyobb. A válság hatására valamelyest visszaesett. Ezt követően viszont újból növekszik, még ha kis mértékben is.

- A leánybankok primer érintettség-görbéi eszköz oldalon inkább az OTP-ére hasonlítanak, mint saját anyabankjaikéra (ld. 1. ábra). A nemzetközi nagybankok vonatkozásában ezért könnyebben hajlunk afelé, hogy a válsághoz vezető egyik fontos közvetítőeszközként nevesítsük a valós értékelés lehetőségét, mint a kisebb hazai hitelintézetek esetében, amelyek követő stratégiára rendezkednek be. A nagybankokra a nagyobb kockázatvállalási hajlandóság is jellemző, hiszen a mérlegfőöszszeghez képest nagyobb azon eszközök és kötelezettségek aránya, amelyek a valós értékelés keretei között kerülnek minősítésre. A válság előtt és után lényegesen nem változott a mérlegfőösszeghez viszonyított primer érintettség.

- A hazai hitelintézeti szektor eszköz oldali valósérték-válságstratégiája ezek szerint eltér a nemzetközi tendenciáktól. Domináns vagyonelemnek számítanak az ügyfelekkel, illetve más hitelintézettekkel szembeni követelések, amelyek amortizált bekerülési értéken kerültek értékelésre.

- Joggal merül fel a kérdés, hogy az eltérő tevékenységi szerkezet és az ezt leképező eltérő mérlegstruktúra szolgálhat-e önmagában is magyarázatul az eltérő valósérték-válságstratégiára. Ehhez szükség volt arra, hogy megvizsgáljuk a követelések arányát, illetve annak időbeli változását. A következő eredményeket kaptuk:

\section{6. táblázat}

Követelések (ügyfelek, hitelintézetek) aránya a mérlegfőösszeghez képest

\begin{tabular}{l|c|c|c} 
& Leány & Anya & OTP \\
\hline Válság előtt & $77,34 \%$ & $62,73 \%$ & $73,88 \%$ \\
\hline Válságban & $71,21 \%$ & $63,11 \%$ & $72,20 \%$ \\
\hline Válság után első periódus & $66,61 \%$ & $62,99 \%$ & $70,34 \%$ \\
\hline Válság után második periódus & $62,56 \%$ & $63,52 \%$ & $57,36 \%$ \\
\hline
\end{tabular}

Forrás: Az aggregált adatok alapján számítva.

Látható, hogy a tevékenység szerkezete, illetve ennek időbeli változása az anyabankok esetében nem okozott érezhető változást a mérlegszerkezetben. Viszont a leánybankok esetében komoly strukturális átalakulás következett be, amihez az OTP kissé megkésve, de annál lendületesebben csatlakozott.

Nyilván több tényezőre vezethető vissza ez az egyértelmúen felismerhető tendencia: a befagyott hitelpiacra, vagy/és a devizahitelek folyamatos kivezetésére, elő- és végtörlesztésekre stb. Ennek vizsgálatát nem tekintjük feladatunknak. Az azonban megállapítható, hogy a mérlegstruktúra jelentősebb eltéréseket anya és leány vi- 
szonylatban inkább a válság előtt mutat. A válság után már nem. Az anyabankok esetében ezért a valós értéken értékelt pénzügyi eszközök aránya csak a válság előtt volt érezhetően magasabb. Feltett kérdésünkre a válasz távolról sem nevezhető egyértelműnek, további vizsgálódást igényel a probléma.

Ugyanez a kérdés a fedezeti ügyletekkel kapcsolatban is: azok eltérő arányaira viszszavezethetők-e a valósérték-válságstratégia eltérései. Megvizsgálva ezt a kérdést is, arra jutottunk, hogy nem, hiszen a hazai leánybankok mérlegeiben a fedezeti ügyletek részesedése marginális. Ezt alig meghaladó mértékű az anyabankok mérlegeiben:

\section{7. táblázat}

A fedezeti ügyletek arányának időbeli változása

\begin{tabular}{l|c|c|c|c|c|c|}
\multicolumn{1}{c|}{ Megnevezés } & \multicolumn{2}{|c|}{ Eszköz oldal } & \multicolumn{2}{c|}{ Forrás oldal } & $\begin{array}{c}\text { Eszköz } \\
\text { oldal }\end{array}$ & $\begin{array}{c}\text { Forrás } \\
\text { oldal }\end{array}$ \\
\cline { 2 - 7 } & Leány & Anya & Leány & Anya & \multicolumn{2}{c}{ OTP } \\
\hline Válság előtt & $0,54 \%$ & $0,44 \%$ & $0,40 \%$ & $0,48 \%$ & $0,09 \%$ & $0,15 \%$ \\
\hline Válságban & $0,34 \%$ & $0,91 \%$ & $0,14 \%$ & $0,73 \%$ & $0,14 \%$ & $0,70 \%$ \\
\hline Válság után első periódus & $0,40 \%$ & $1,32 \%$ & $0,43 \%$ & $1,23 \%$ & $0,13 \%$ & $0,85 \%$ \\
\hline Válság után második periódus & $0,61 \%$ & $0,88 \%$ & $0,25 \%$ & $1,06 \%$ & $0,23 \%$ & $0,69 \%$ \\
\hline Átlag (2006-2015) & $0,49 \%$ & $0,88 \%$ & $0,31 \%$ & $0,90 \%$ & $0,15 \%$ & $0,56 \%$ \\
\hline
\end{tabular}

Forrás: Az aggregált adatok alapján számítva.

\subsection{Az empirikus vizsgálat legfontosabb eredményei a szekunder érintettség vonatkozásában (Id: 4., 5. táblázat)}

\subsubsection{Időbeli tendenciák}

A válság előtti helyzethez képest az ezt követő időszakokban (különösen a stabilizáció második periódusában) az eszköz és a forrás oldalon is azt láthatjuk, hogy a 3. szint szerepe erősen visszaszorult, azaz a mérleg mindkét oldalán határozott törekvések nyomai fedezhetők fel arra nézve, hogy a piaci szereplők a valósérték-érintettségük belső struktúráját átalakítsák a 3. szint rovására. Ez a reakció egyértelműen kockázatcsökkentésként fogható fel, vagy legalábbis világos üzenetet hordoz a potenciális befektetők felé, mely üzenet a mérlegek „nagyobb kockázatú elemektől” való megtisztítását ígéri. Érdekes módon a leányvállalatok és az OTP viszonylatában ez a hatás kevésbé erős, mint az anyabankok esetében, ami alapvetően két okra vezethető vissza. Egyrészt az önálló banki döntésekre, másrészt a hazai pénzügyi szabályozás változásaira. Különösen igaz ez az OTP-re. A 2010. év során a magyarországi önkormányzati szektorban kibocsátott kötvényeket ugyanis átsorolták a hitelek közé. Az önkormányzati kötvényeknek sajnos nem alakult ki hazánkban aktív piaca, így a hitelintézetek releváns piaci értéket nem tudtak e kötvényekhez hozzárendelni. Az adott instrumentum számviteli tartalmának elemzése alapján megállapították, hogy 
megfelelnek az IAS 39 standardjának, azaz hitelként, követelésként definiálhatók, így valós érték helyett amortizált bekerülési értéken kerültek a későbbiekben értékelésre. A másik hatás az egyedi banki döntésen alapuló értékelésváltozás, ami az OTP esetében a devizában denominált jelzáloghitelek árfolyamkockázatának fedezésére kialakított hedge-ügyletekben keresendő. A tőkecserés kamatswap értékelésekor az EUR/CHF felárakra vonatkozó spekulációk miatt a piacon megfigyelhető jegyzéseket kevésbé megbízhatónak ítélte a bank, ezért úgy döntött, hogy az érintett portfóliót a 2. szintből átsorolja a 3. szintbe. Az információk minőségének javulásával 2012ben visszasorolták azokat a 2. szintre. A leányvállalatok esetében is hasonló volt a helyzet. A fedezeti ügyletek értékének mérését piaci alapú megmérettetés helyett a modell alapú értékelés váltotta fel. Ezzel magyarázható az adott periódus enyhén növekvő adata.

Válságban (2008-2009) és az azt követő időszakban (2010-2011) az anyavállalatok óvatos magatartása volt a jellemző a valós értékelés terén. Felülvizsgálták a tisztán piaci információk alapján értékelt, az 1. szintbe sorolt eszközeik és forrásaik értékének megbízhatóságát. Az adott időszak üzleti és piaci információinak megbízhatósága ugyanis erőteljesen megkérdőjeleződött. Az általános volatilitásemelkedés miatt egyes instrumentumok jelentős ár- vagy árfolyam-ingadozásokat voltak kénytelenek elviselni, így az újra és újra elvégzett értékelések eredményeivel szemben megingott a bizalom. A nem egyértelmű eredmények miatt a tisztán piaci alapú információk szerint történő értékelés helyett a pénzügyi modellekkel kiegészített, korrigált értékelések kerültek egyre nagyobb arányban alkalmazásra. Ezt tapasztalhatjuk az eszközök (4. táblázat) 2. szinti arányainak emelkedésében a korábbi időszakhoz képest. A válság utáni második periódusban ezek a hatások már megszűntek, és a folyamat visszájára váltott. Újból az 1. szint aránya növekedett a 2. és 3. szint rovására, mivel a piaci adatok egyre megbízhatóbbak lettek, és a volatilitás csökkent.

A speciális hazai hatásmechanizmusok ellenére tényként rögzíthetjük, hogy a hazai hitelintézeti szektorban a 3. szint súlya válság után a második periódusban már általában lényegesen alacsonyabb, mint a válság előtt volt, azaz kis fáziskéséssel, de követjük az anyabankoknál eklatánsabban megjelenő kockázat-szétporlasztási törekvéseket, tendenciákat.

\subsubsection{A mérleg és a valós értékelési szintek strukturális tendenciái}

Eszköz oldalon az látszik, hogy a vizsgált időszak végére minden szereplő a válság előtti arányszám fölé emelte az 1. szint súlyát. Így az 1. szint egyértelmúen domináns szerepet játszik a valósérték-érintettségben, ami a piaci információk megbízhatóságának javulására és arra az egyértelmű törekvésre vezethető vissza, hogy a hazai hitelintézeti szereplők a válságból való kilábalás egyik eszközének tekintették a mérleg- és a valósértékszint-struktúra olyan irányú módosítását, aminek egyértelmű üzenete a befektetők felé a kockázatcsökkentés szándéka. 
Így kívántak egyre inkább és egyre erősebben megfelelni a standard valós értékeléssel kapcsolatos előírásainak, miszerint az azt alkalmazni kívánó gazdálkodó egység tegyen meg mindent annak érdekében, hogy minél nagyobb arányban megbízható, piaci információkat használjon fel az értékeléshez.

Forrás oldalon látszik a 2. szint meghatározó szerepe. Ez elsősorban a fedezeti ügyleteknek tudható be, amelyek értékelésében fontos elem a piaci adat, ami nem feltétlenül közvetlenül áll rendelkezésre. Más instrumentumok piaci árából, árfolyamából származtatva, a szükséges korrekciók elvégzése után lehetséges a végső mérlegérték meghatározása. De valamilyen szinten minden esetben szükség van értékelés-módszertani apparátus bevetésére. A források oldalán is egyébként teljesen hasonló strukturális módosulások következtek be, mint az eszközök oldalán.

Megállapításaink tehát összecsengenek a szakirodalomban feltárt összefüggésekkel. A válság egyértelműen hatást gyakorol a valósértékelés-stratégiára, hiszen olyan alkalmazkodási mechanizmusokat hív életre, amelyek fö célja a valós értékelésben rejlő pótlólagos kockázat csökkentése. Ez egyben azt is jelenti, hogy a valósértékelés-stratégia közvetve visszahat a válságra, hiszen hatást gyakorol a piaci kockázati szintre. Ilyen értelemben különösen a 3 . szint súlyának lehet komoly szerepe a válságból való kilábalás lehetséges eszközeként.

\subsection{A valós érték érintettség mint kockázati mutató}

Megvizsgáltuk azt is, hogy az egyes szintek a vizsgált időszakokban milyen szerepet játszottak a mérleg eszköz és forrás oldalán. Kiemelt szerepet adtunk e tekintetben a 3. szintnek, hiszen ez a legkockázatosabb, mert ezen a szinten az értékelés modellek segítségével történik. Vizsgálódásunkat az eszköz oldalra szűkítettük, mert a forrás oldalon a mindenkori mérlegfőösszeghez viszonyítva elhanyagolható mértékü a 3. szint súlya.

Ez már egy kellőképpen aggregált és optimalizált mutatószám, amit joggal nevezhetünk a valósértékelés-érintettség kockázati mutatószámának, ami arra is rávilágít, hogy milyen mértékú a „kockázatos” tételek súlya a mérlegekben (eszköz oldal). Ez a mutatószám alkalmas lehet arra, hogy a valós értékelés pótlólagos kockázatát egy számba sürítve a befektetők számára fontos információkat közvetítsen a hitelintézet valós számviteli politikájáról, illetve annak a kockázati kitettségre gyakorolt hatásáról.

Kiszámításának módja roppant egyszerü: a primer és a szekunder érintettségi mutatószámokat szintenként rendre össze kell szorozni egymással, s így megkapjuk az egyes szintek súlyát a mérlegfőösszeghez viszonyítva.

Az eszközök oldalán a 3. szint szerepének bemutatására törekszünk, mivel ez az a szint, amely jelentéstartalmánál fogva a legnagyobb befektetői kockázatot hordozhatja. 


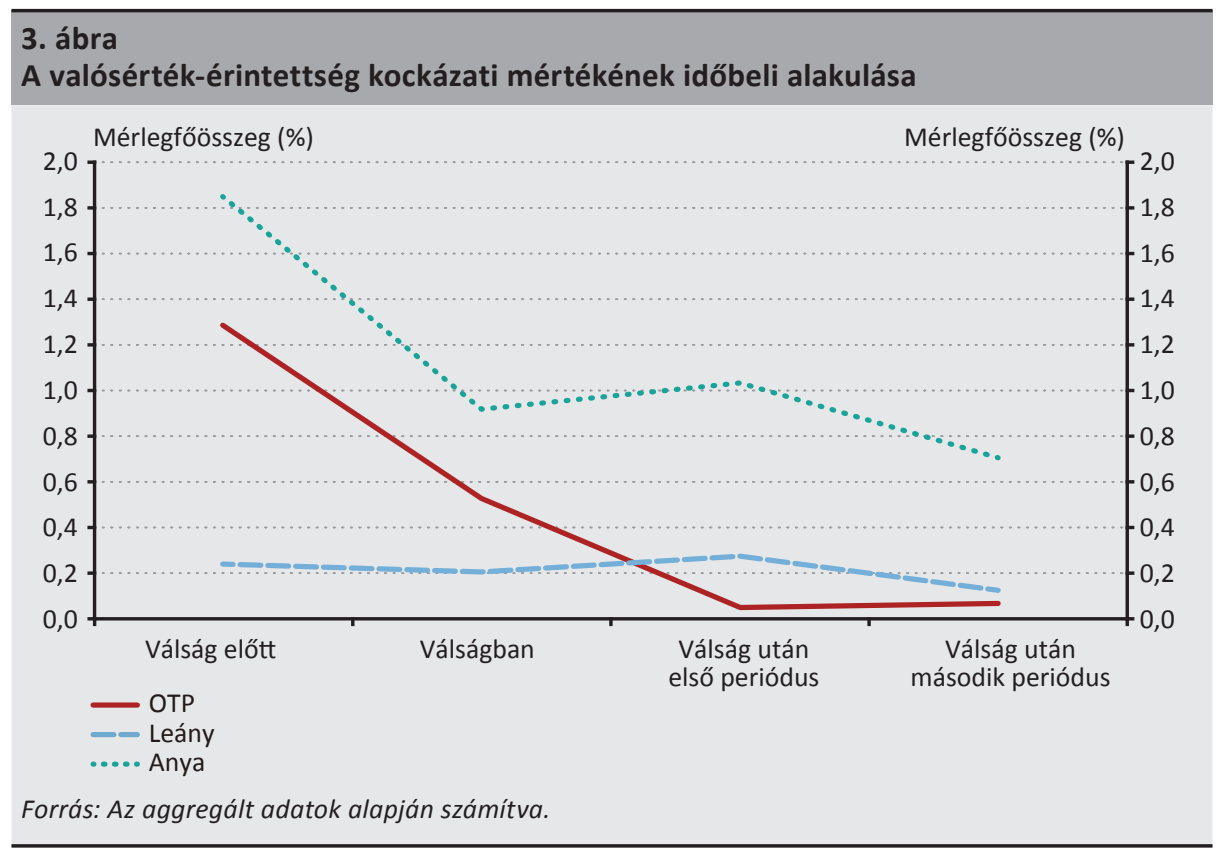

A 3. ábrából világosan leolvashatók a tendenciák. A nemzetközi anyabankok válság előtt lényegesen nagyabb arányban éltek a 3. szint lehetőségével, mint hazai leánybankjaik vagy az OTP. Ez a különbözet lényegében a válság alatt és azt követően sem változott, csak az az óriási különbség, hogy a válság után az ebben rejlő kockázat megfeleződött, hiszen a 3 . szint súlya a válság előttinek alig a fele.

A szereplők reakciója igen gyors volt. Igyekeztek eltolni a 3. szinten valós értékeléssel érintett eszközeik nagy részét az 1 . és 2 . szintek felé, amivel a 3. szint szerepe és súlya mérlegeikben egyre kisebb lett. A leánybankok és az OTP ilyen típusú kockázata kiegyenlítetté vált, ugyanakkor az anyabankok kitettsége (mérlegfőösszeghez viszonyított aránya) még mindig közel hatszorosa a hazai átlagnak.

Ha a mérlegfőösszegek nagyságrendjét is figyelembe vesszük, és nem csak az ehhez viszonyított arányokat, akkor becslésünk szerint (a mindenkori átlagos éves devizaárfolyamokkal kalkulálva) az anyabankok mérlegeinek eszköz oldalán a 3. szinttel érintett összeg válság előtt átlagosan közel 140 millió euróra volt tehető, ami a 4. periódusra harmadára esett vissza. Ehhez képest a hazai leánybankok és az OTP elhanyagolható mértékben érintett csupán. 


\section{6. Összegzés és kitekintés}

Megállapításunk szerint a valósérték-érintettség három szinten mérhető:

- primer érintettség alatt az egyes mérlegtételek főösszeghez viszonyított arányait értjük, ami elsődleges tájékozódási pont a valós értékelés kiterjedtségéről;

- szekunder érintettségnek azt nevezzük, amikor az érintettség valós értékelési szintenkénti struktúráját mérjük, szintén a mérlegfőösszeg arányában;

- a valósértékelés-érintettség mint kockázati mutatószám véleményünk szerint akkor alkalmazható, ha a 3. szint eszköz oldali súlyát fejezzük ki a mérlegfőösszeg arányában.

A valós értékelés - válság kapcsolatáról szóló szakirodalomban kibontakozott vitához annyi adalékot tudtunk hozzátenni, hogy a hazai hitelintézeti szektorban a válság egyértelmüen kimutatható alkalmazkodási mechanizmusokat hozott létre, amelyek a valósérték-érintettségben rejlő pótlólagos kockázatok csökkentésében realizálódtak.

Megállapítottuk, hogy az alkalmazkodás az anya- és leánybankok esetében nem egy ütemben és nem homogén módon zajlott le. Meglátásunk szerint ennek egyik legfőbb oka az lehetett, hogy a hazai szereplők nem éltek olyan mértékben a valós értékelés nyújtotta lehetőségekkel, mint a vizsgálatba vont anyavállalatok.

Ezen megállapításunkat az eredménnyel és a saját tőkén belül, az értékelési tartalékkal ${ }^{9}$ szemben értékelt eszközök arányának jelentős eltéréseivel magyarázzuk, amelyek a következők:

\section{8. táblázat}

Eredménnyel szemben versus saját tőkén belül, az értékelési tartalékkal (OCI) szembeni elszámolások átlagos arányai a vizsgált időszakban

\begin{tabular}{l|c|c|c} 
Megnevezés & Leány & Anya & OTP \\
\hline Eredménnyel szemben értékelt eszközarány & $20,34 \%$ & $59,88 \%$ & $11,43 \%$ \\
\hline OCl-val szemben értékelt eszközarány & $79,66 \%$ & $40,12 \%$ & $88,57 \%$ \\
\hline Forrás: Az aggregált adatok alapján számítva.
\end{tabular}

Látható, hogy a hazai leányvállalatok (és az OTP), ahogy arra korábban már utaltunk, az óvatosabb értékelési technikákat részesítik előnyben. Az anyavállalatok ezzel szemben az értékelési különbözet elszámolása tekintetében az eredménnyel

\footnotetext{
${ }^{9}$ A nemzetközi szakirodalom szerint egyéb átfogó eredménnyel (Other Comprehensive Income, OCI) szemben értékelt elemek.
} 
szembeni elszámolást priorizálják. Az anyavállalatok ezért nagyobb arányban élnek a valós értékelés adta rugalmas lehetőségekkel, mint a hazai leányvállalatok.

Természetesen nem gondoljuk azt, hogy ezzel kutatásunk véget ért. Sok tekintetben éppen az történt, hogy legalább annyi kérdést hagyott nyitva, mint amennyit megválaszolt. Ezért több publikáció is fogja követni, hiszen az értékrelevancia-vizsgálatok és a hitelintézeti szférán kívüli értékmérési gyakorlat még nagyon sokban segíthetik megállapításaink általános elfogadhatóságát, ezért további kutatásaink erre irányulnak majd a közeli jövőben.

\section{Felhasznált irodalom}

Allen, F. - Carletti, E. (2008): Mark-to-Market Accounting and Liquidity Pricing. Journal of Accounting and Economics, 45(2-3): 358-378. https://doi.org/10.1016/j. jacceco.2007.02.005.

Bagna, E. - Di Martino, G. - Rossi, D. (2014): An Anatomy of The Level3 Fair Value Hierarchy Discount. DEM Working Papers Series from University of Pavia, Department of Economics and Management. No 65: 46. https://papers.ssrn.com/sol3/papers.cfm?abstract_ id=2367405. Letöltés ideje: 2016 . november 15.

Barth, M. E. - Gómez-Biscari, J. - López-Espinosa, G. (2012): Fair Value Accounting, Earnings Management and the use of Available-for-Sale Instruments by Bank Managers. Working Paper, Universidad de Navarra, N05/12: 1-52.

Barth, M., (2004): Fair Values and Financial Statement Volatility. In: Borio, C. - Hunter, W.C. - Kaufman, G. G - Tsatsaronis, K. (ed.): The Market Discipline Across Countries and Industries. Cambridge, Massachusetts, MIT Press: 323-333.

Bélyácz Iván (2013): A befektetések és a tökepiac. Budapest, Akadémiai Kiadó.

Beneish, M. D. (1999): The detection of earnings manipulation. Financial Analysts Journal, 55: 24-36. https://doi.org/10.2469/faj.v55.n5.2296.

Bosch, P. (2012): Value relevance of the fair value hierarchy of IFRS 7 in Europe - How reliable are mark-to-model fair values? Working Papers University of Fribourg, SES, 439: 1-36.

Bromwich, M. (2007): Fair values: imaginary prices and mystical markets. In: P. Walton (szerk.): The Routledge Companion to Fair Value and Financial Reporting, Routledge/ Taylor \& Francis Group, London: 46-67. https://doi.org/10.4324/NOE0415423564.ch5.

Christensen, H. B. - Nikolaev, V. V. (2013): Does Fair Value Accounting for Non-Financial Assets Pass the Market Test? Review of Accounting Studies January: 734-775. https:// doi.org/10.1007/s11142-013-9232-0. 
Goh, B. W. - Ng, J. - Yong, K. O. (2009): Market pricing of banks' fair value assets reported under SFAS 157 during the 2008 economic crisis. Working Paper, Massachusetts Institute of Technology and Singapore Management University.

Gorton, G. B. (2008): The Panic of 2007. NBER Working Paper No. 14358. September: 1-91. https://doi.org/10.3386/w14358.

Greenberg, M. D. - Hellen, E. - Clancy, N. - Derteuzos, J. N. (2013): Fair value accounting, historical cost accounting and systemic risk. RAND Corporation.

Hitz, J. M. (2005): The Decision Usefulness of Fair Value Accounting - A Theoretical Perspective. European Accounting Review, vol. 16, issue 2: 323-362.

Kolev, K. (2008): Do investors perceive marking-to-model as marking-as-myth? Early evidence from FAS 157 disclosure. https://doi.org/10.2139/ssrn.1336368.

Kovács D. M. (2012): A valós értékelés új keretrendszere a nemzetközi pénzügyi beszámolásban. Hitelintézeti Szemle. 2: 161-181.

Laux, C. - Leuz, C. (2009a): Did Fair-Value Accounting Contribute to the Financial Crisis? Journal of Economic Perspectives, Vol. 24, issue 1: 93-118. http://doi.org/10.1257/ jep.24.1.93.

Laux, C., - Leuz, C. (2009b): The crisis of Fair value accounting: making sense of the recent debate. Accounting, Organisations and Society, vol. 34, August (6-7): 826-834.

Le Pan, N. (2008): Whither Financial Regulation? Bank of Canada. A Festschrift in Honour of David Dodge. November: 25-78.

Magnan, M. (2009): Fair Market Value and the Financial Crisis: Messenger or Contributor? Accounting Perspectives 8(3): 189-213. https://doi.org/10.1506/ap.8.3.1.

McFarland, J. - Partridge, J. (2008): Mark-to-market' accounting rules fuel debate. The Globe and Mail Report on Business. November 20. https://www.theglobeandmail.com/reporton-business/mark-to-market-accounting-rules-fuel-debate/article1350755/. Letöltés ideje: 2016. november 15.

Pitz Mónika - Schepp Zoltán (2013): A banki hitelek árazásának vizsgálata strukturális VAR modell segítségével. Pénzügyi Szemle 58(4): 434-447.

Power, M. (2010): Fair value accounting, financial economics and the transformation of reliability. Accounting and Business Research, 40(3): 197-210. https://doi.org/10.1080 /00014788.2010.9663394.

Pozen (2009): Is It Fair to Blame Fair Value Accounting for the Financial Crisis? HBR, november: 1-10. 
Rérolle, J.F. (2008): The fair value debate: from accounting utopia to financial realism. Revue Trimestrielle de Droit Financier no. 4: 1-12.

Riedl, E. J. - Serafeim, G. (2011): Information Risk and Fair Value: An Examination of Equity Betas. Journal of Accounting Research 49: 1083-1122. https://doi.org/10.1111/j.1475679X.2011.00408.x.

Sarkozy, M.N. (2008): International financial crisis. Speech by M. Nicolas Sarkozy, President of the Republic, 25 September.

Shaffer, S. (2012): Evaluating the Impact of Fair Value Accounting on Financial Institutions: Implications for Accounting Standards Setting and Bank Supervision. Federal Reserve Bank of Boston. WPS No. QAU 2012-01: 1-60.

Shamkuts, V. (2010): Fair Value Accounting. BS Thesis, University of Iceland. https:// skemman.is/bitstream/1946/4234/1/Thesis_fixed.pdf. Letöltés ideje: 2016. november 15.

Song, C. J. - Thomas, W. B. - Yi, H. (2010): Value relevance of FAS No. 157 fair value hierarchy information and the impact of corporate governance mechanisms. The Accounting Review, 85(4): 1375-1410. https://doi.org/10.2308/accr.2010.85.4.1375.

Takács, A. (2015): Vállalatértékelés magyar számviteli környezetben. Második, bővített kiadás, Perfekt.

Takacs, A. (2014): The Relationship between Appraised Company Values and Future Stock Prices in the International Banking Sector. International Research Journal of Finance and Economics, 118: 113-123.

Veron, N. (2008): Fair Value Accounting is the Wrong Scapegoat for this Crisis. European Accounting Review, 5(2): 63-69. https://doi.org/10.1080/17449480802510542.

Wallison, P. J. (2008): Fair value accounting: A critique. American Enterprise Institute for Public Policy Research Outlook Series: 1-8.

Whalen, R. C. (2008): The subprime crisis: causes, effect and consequences. Networks Financial Institute Policy Brief No. 2008-PB-04. https://doi.org/10.2139/ssrn.1113888. 